\title{
In vitro Maturation and Fertilization of Riverine Buffalo Follicular Oocytes in Media Supplemented with Oestrus Buffalo Serum and Hormones
}

\author{
H. JAMIL, H.A. SAMAD, N.U. REHMAN, Z.I. QURESHI, L.A. LODHI \\ Department of Animal Reproduction \\ Faculty of Veterinary Science, University of Agriculture, Faisalabad, Pakistan \\ Received August 11, 2006 \\ Accepted August 27, 2007
}

\begin{abstract}
Jamil H., H.A. Samad, N.U. Rehman, Z.I. Qureshi, L.A. Lodhi: In vitro Maturation and Fertilization of Riverine Buffalo Follicular Oocytes in Media Supplemented with Oestrus Buffalo Serum and Hormones. Acta Vet. Brno 2007, 76: 399-404.

Effects of two maturation media (TCM-199 and Ham's F-12) with and without the addition of oestrus buffalo serum (OBS) and hormones (FSH, LH, E2) on the maturation rate of buffalo follicular oocytes were evaluated. The results revealed a significant $(P<0.05)$ increase in the maturation rate when the OBS and hormones were added to TCM-199 than in Ham's F-12 medium. The percentage of maturation rates in TCM-199 + hormones + OBS, TCM-199 + hormones, TCM-199 + OBS and TCM-199 were 77.44, 55.17, 62.28 and 26.62 percent, respectively. While in Ham's F-12 + OBS + hormone, Ham'F-12 + hormone, Ham's F-12 + OBS and Ham's F12 were $32.85,27.52,31.38$ and 13.46 percent, respectively. A significantly higher $(P<0.05)$ fertilization rate was recorded for modified $\mathrm{Ca}^{2+}$ free Tyrode's medium $(63.72 \%)$ than in TALP $(10.9 \%)$ and IVF-TL $(32.18 \%)$. Thus, TCM-199 containing hormones and OBS appeared better for in vitro maturation, whereas modified $\mathrm{Ca}^{2+}$ free tyrode's medium was found to be more suitable for in vitro fertilization of buffalo follicular oocytes.
\end{abstract}

Reproduction, Bubalus bubalis, TCM-199, Ham's F-12, FSH, LH, E2

Riverine buffaloes (Bubalus bubalis) are hardy dairy animals, resistant to climate, stress and diseases. However, problems like delayed onset of reproductive maturity, seasonality of breeding, long calving interval, latent oestrus, low number of primordial follicles and poor superovulatory response have been attributed to poor reproductive performance of this species (Nandi et al. 2002).

In vitro maturation (IVM) and in vitro fertilization (IVF) procedures performed on oocytes obtained from slaughter-house derived ovaries have recently provided a practical means for producing large number of bovine zygotes at low cost for research and commercial settings (Hansen 2006). Application of this technology in assisted reproduction of buffalo will not only improve productive and reproductive potential of the buffalo population but will also help rescue the precious germ plasma going to waste by indiscriminate slaughter of this animal.

The acquisition of more insights into the buffalo culture requirements is critical to optimize the efficiency of advanced reproductive strategies in this species. Lack of proper conditions to support in vitro culture of buffalo zygotes to a transferable stage embryo is the major impediment in the successful buffalo IVF system. The direct extrapolation of the methods from cattle to the buffalo resulted in poor fertility. Chauhan et al. (1997) reported that oocyte maturation and cleavage rates in buffalo are lower than those for cattle. There have been reports to enhance early development of in vitro produced embryos in domestic animals by addition of hormones, sera and somatic cells (Pawshe et al. 1996). To optimize in vitro embryo production of buffalo by improving the culture conditions, the present project was designed: 1) to assess the effect of addition of sera and hormones on in vitro maturation of buffalo oocytes and 2) to evaluate media in supporting fertilization of in vitro matured oocytes.

Address for correspondence:

H. Jamil

Department of Animal Reproduction

Faculty of Veterinary Science

University of Agriculture

E-mail: drhjamil@hotmail.com

Faisalabad 38040, Pakistan

http://www.vfu.cz/acta-vet/actavet.htm 


\section{Materials and Methods}

\section{Collection of oocytes}

Ovaries from sexually mature buffaloes were collected within $30 \mathrm{~min}$ after slaughter from the local abattoir and transported to the laboratory in a vacuum flask containing sterilized phosphate buffered saline (PBS: at $\mathrm{pH}$ 7.35) supplemented with 100 i.u. penicillin $\mathrm{G}$ and $100 \mu \mathrm{g} / \mathrm{ml}$ of streptomycin at the temperature maintained at $25-30{ }^{\circ} \mathrm{C}$ (Chauhan et al. 1997). In the laboratory extraneous tissue was removed and ovaries were washed with $70 \%$ ethanol, followed by three rinses in PBS. Cumulus oocyte complexes (COC's) were recovered by scoring method (Samad et al. 1998). Oocytes possessing a full cumulus mass, unfragmented cytoplasm and intact zona were selected for further processing.

\section{In vitro maturation}

For in vitro maturation of COC's, two types of culture media were used: a) Tissue Culture Medium 199 (TCM199 Sigma) and b) Ham's Nutrient mixture F12 (Ham's F-12 Sigma) either with or without the addition of Follicle Stimulating Hormone (FSH: $5 \mu \mathrm{g} / \mathrm{ml}$ ), Lutenizing Hormone (LH: $5 \mu \mathrm{g} / \mathrm{ml})$, Estradiol 17- $\beta$ (1.5 $\mu \mathrm{g} / \mathrm{ml})$ and gentamycin $10 \mu \mathrm{g} / \mathrm{ml}$ (Sigma). To study the effect of oestrus buffalo serum (OBS) on the maturation rate of buffalo follicular oocytes, the media with and without the addition of OBS $(20 \%)$ were prepared. The $\mathrm{pH}$ of all the media was adjusted to 7.3 - 7.4. Drops of $200 \mu \mathrm{l}$ of maturation media were prepared in a Petri dish covered with mineral oil and equilibrated in the incubator providing atmosphere containing $5 \% \mathrm{CO}_{2}$ and $95 \%$ humidity.

Selected oocytes were washed four times in fresh pre-warmed TL-Hepes medium and subjected to a final wash with in vitro maturation medium before transferring to the drops. Batches of $10-20$ oocytes were then transferred to the drops of TCM-199 and Ham's F-12 in different containing; i) hormones; ii) hormones and OBS; iii) OBS without hormones and iv) without hormones and OBS. The drops in Petri dishes were covered with sterile mineral oil (Sigma) and were incubated at $39^{\circ} \mathrm{C}$ in $5 \% \mathrm{CO}_{2}$ in air for $24 \mathrm{~h}$. The maturation of oocytes was evaluated under stereomicroscope. Oocytes having expanded cumulus cells with extrusion of the polar body were considered matured. Oocytes matured in TCM-199 containing hormones + OBS, hormones or OBS only were subjected further to in vitro fertilization.

\section{In vitro fertilization}

Fertilization media i.e. Tyrode - albumin - lactate - pyruvate (TALP), modified $\mathrm{Ca}^{2+}$ free Tyrode's and IVFTL media were used to determine the fertilization rate of the in vitro matured buffalo follicular oocytes. For IVF, modified $\mathrm{Ca}^{2+}$ free Tyrode, IVF-TL or TALP media's adjusted to $\mathrm{pH} 7.8$ were used. Fresh semen from a buffalo bull was used for the insemination of matured oocytes. For capacitation spermatozoa were prepared using swim up method described by Chohan and Hunter (2003) with modified $\mathrm{Ca}^{2+}$ free Tyrode medium. The sperm concentration was adjusted to $1 \times 10^{6}$ for the insemination of oocytes, and $50 \mu 1$ drops of three types of fertilization media were prepared i) TALP ii) IVF-TALP and iii) Modified $\mathrm{Ca}^{2+}$ free Tyrode medium. Batches of oocytes (5 - 10/drops) and sperm cells were co-cultured in the incubator at $39{ }^{\circ} \mathrm{C}$ with $5 \% \mathrm{CO}_{2}$ and humidified air for $24 \mathrm{~h}$. Fertilization/cleavage rates in different media were recorded.

\section{Statistical analysis}

In a $4 \times 2$ factorial experiment, 702 COCs were randomly assigned to 8 treatment groups to evaluate the effect of maturation media and supplementation, whereas 198 IVM oocytes were randomly assigned to 3 treatment groups to determine the effect of media on the fertilization rate. The percentage of oocytes reaching the designated response variables in each replicate were determined and used in the analysis. The data thus obtained were subjected to analysis of variance to see the magnitude of variation among various treatment groups using M StatC (version 1.3) software.

\section{Results and Discussion}

The effect of two maturation media i.e. TCM-199 and Ham's F-12 with the addition of oestrus buffalo serum (OBS) and hormones or OBS and hormones alone on the maturation rate of buffalo follicular oocytes is given in Table 1 . The results revealed a significant $(P$ $<0.05)$ increase in maturation rate when the OBS and hormones were added separately or in combination to TCM-199 than in Ham's F-12 medium. The percentage of maturation in TCM-199 with supplementation of OBS and hormones was significantly higher (77.44 $\pm 0.68)$ than in Ham's F-12 (32.85 \pm 0.83$)$. Similarly, supplementation of TCM-199 with hormones or OBS alone also significantly improved the maturation rate of buffalo follicular oocytes than by Ham's F-12 in these combinations.

Proper maturation is essential for an oocyte to achieve full developmental competence for fertilization. A number of ultrastructural and molecular changes occurring during oocyte development are linked to the developmental competence of the gamete (Hyttel 1997). The culture medium employed for IVM of follicular oocytes not only affects the proportion 
Table 1. Effect of maturation media with supplementation of oestrus buffalo serum and hormones on maturation rate of buffalo follicular oocytes

\begin{tabular}{|c|c|c|}
\hline \multirow{2}{*}{} & \multicolumn{2}{|c|}{ Maturation media } \\
\cline { 2 - 3 } & $\begin{array}{c}\text { TCM-199 } \\
\text { Mean \% } \pm \text { S.E.M. }\end{array}$ & $\begin{array}{c}\text { Ham's F-12 } \\
\text { Mean \% } \pm \text { S.E.M. }\end{array}$ \\
\hline $\begin{array}{c}\text { EBS + } \\
\text { Hormone } \\
(\mathrm{n})\end{array}$ & $\begin{array}{c}77.44 \pm 0.68^{\mathrm{a}} \\
(148 / 191)\end{array}$ & $\begin{array}{c}32.85 \pm 0.83^{\mathrm{e}} \\
(53 / 161)\end{array}$ \\
\hline $\begin{array}{c}\text { EBS - } \\
\text { Hormone } \\
(\mathrm{n})\end{array}$ & $\begin{array}{c}55.17 \pm 2.7^{\mathrm{b}} \\
(92 / 167)\end{array}$ & $\begin{array}{c}27.52 \pm 1.62^{\mathrm{d}} \\
(44 / 161)\end{array}$ \\
\hline $\begin{array}{c}\text { EBS + } \\
\text { Hormone }- \\
(\mathrm{n})\end{array}$ & $\begin{array}{c}62.28 \pm 0.51^{\mathrm{d}} \\
(109 / 175)\end{array}$ & $\begin{array}{c}31.38 \pm 1.77^{\mathrm{e}} \\
(59 / 188)\end{array}$ \\
\hline $\begin{array}{c}\text { EBS - } \\
\text { Hormone } \\
(\mathrm{n})\end{array}$ & $\begin{array}{c}\left(4.62 \pm 0.75^{\mathrm{e}}\right. \\
(45 / 169)\end{array}$ & $\begin{array}{c}13.46 \pm 0.55^{\mathrm{f}} \\
(21 / 156)\end{array}$ \\
\hline
\end{tabular}

The values with different superscripts in the row and column differ significantly $(P<0.05)$

EBS: Oestrus Buffalo Serum

Hormone : $\mathrm{E}_{2}(1.5 \mu \mathrm{g} / \mathrm{ml}), \mathrm{FSH}(5 \mu \mathrm{g} / \mathrm{ml}), \mathrm{LH}(5 \mu \mathrm{g} / \mathrm{ml})$

TCM-199 : Tissue culture medium-199 (Sigma)

Ham's F-12 : Ham's nutrient mixture F-12 (Sigma)

$$
\begin{aligned}
& \text { : Present } \\
& \text { : Absent }
\end{aligned}
$$

of oocytes that reach the metaphase II and become capable of undergoing fertilization, but also influences subsequent embryonic development (Rizos et al. 2002). Therefore development of a suitable culture system for IVM of oocytes is a major component of in vitro embryo production procedures. In this study, when comparing two media without supplementation (Ham's F-12 and TCM-199), a significant difference for maturation rate was found between the two media. Moreover, the addition of serum and hormones to TCM-199 was superior to Ham's F-12 for supporting maturation of buffalo follicular oocytes. Oocytes matured in TCM-199 with serum and hormones had a significantly higher $(P<0.05)$ maturation rate than in Ham's F-12 with these combinations. A variety of media have been used for in vitro maturation of follicular oocytes. However, higher maturation rates in TCM-199 than in Ham's F-12 have been reported previously (Pawshe et al. 1996; Smetanina et al. 2000).

The results of this study revealed that the addition of serum to the TCM-199 medium enhanced the maturation rate of follicular oocytes. Similar findings have been reported by Russell et al. (2006) in cattle. Kito and Bavister (1997) found a favourable effect of oestrus cow serum when added to the maturation medium. These authors have postulated that the addition of sera to the culture medium during the maturation of oocytes promotes the rupture of germinal vesicle and induces oocyte maturation. Hence, supplementation of the media with serum had a biphasic favourable effect on maturation. The beneficial effects of serum for oocyte maturation may also act via cumulus cells or directly on the oocytes. The serum contains a number of known growth factors that have an important role in the regulation of oocyte maturation, particularly via cumulus cells it also prevents the hardening of the zona pellucida; moreover, the beneficial action of serum may be due to its anti-oxidant properties (Mahmoud and Nawito 2003).

The role of gonadotrophins on IVM of oocytes has also been demonstrated by earlier workers. Oocytes matured in vitro in the presence of gonadotrophins and estradiol had 
higher maturation rates compared with maturation protocols, in which no hormones were added (Choi et al. 2001). With the addition of gonadotrophins to the culture medium, resumption of meiosis was improved (Tatemoto and Terada 1998). Gonadotrophins and estradiol cause synergistic enhancement of nuclear maturation in mammalian oocytes in vitro (Pawshe et al. 1996). Oocytes matured in vitro in the presence of gonadotrophins and estradiol showed higher maturation and fertilization rates compared with those of without hormones (Abdoon et al. 2001). Tatemoto and Terada (1998) reported that FSH stimulation may play in the complex mechanism of chromatin condensation leading to meiotic resumption in the oocytes and $\mathrm{LH}$ in the medium enhanced expansion of cumulus cells (Gliedt et al. 1996), whereas estradiol improved the fertilizing ability of bovine oocytes cultured in vitro.

The addition of $20 \%$ OBS with gonadotrophins and estradiol in TCM-199 or Ham's F-12 resulted in better maturation rates of buffalo follicular oocytes than medium containing only OBS (Chauhan et al. 1996; Abdoon et al. 2001). Kito and Bavister (1997) reported that the effects of gonadotropins on nuclear maturation, cumulus expansion and oocyte morphology are modulated by serum. Mahmoud and Nawito (2003) reported that oestrus buffalo serum containing gonadotrophins could be a suitable substitute to foetal calf serum for the culturing of buffalo oocytes. Similar results have been reported by Gliedt et al. (1996). The results of present study concluded that the addition of gonadotrophins and estradiol to TCM-199 supplemented with $20 \%$ OBS is quite favourable for IVM of buffalo follicular oocytes.

In the present study a significantly higher $(P<0.05)$ fertilization rate $(\%)$ was recorded for modified $\mathrm{Ca}^{2+}$ free Tyrode's medium $(63.72 \pm 2.33)$ than in TALP $(10.9 \pm 0.99)$ or IVF-TL (32.18 \pm 1.61$)$ media (Table 2). Ijaz and Hunter (1989) stated that capacitation of sperm in $\mathrm{pH} 7.6 \mathrm{Ca}^{2+}$ free Tyrode's medium for 4 to 8 hours resulted in the highest penetration rate to zona-free hamster oocytes. They also found that fresh semen gave better IVF rates than frozen-thawed semen. The modified $\mathrm{Ca}^{2+}$ free Tyrode's medium stimulated the sperms to undergo changes which preceded the acrosome reaction and the $\mathrm{pH}$ of the medium precluded the necessity for calcium. No earlier work in $\mathrm{Ca}^{2+}$ free medium is known to the author for IVF in the buffalo that may be compared with the present findings. The results of the present study indicate that modified $\mathrm{Ca}^{2+}$ free Tyrode's medium not only improved sperm quality as a sperm preparation medium, but also enhanced fertilization/ cleavage rate as an in vitro fertilization medium. The rate of fertilized/cleaved oocytes was significantly lower in $\mathrm{Ca}^{2+}$ containing TALP and IVF-TL media. This indicates that calcium may not be necessary for the sperm to fertilize the oocytes.

Table 2. Effect of fertilization media on fertilization rate of buffalo follicular oocytes

\begin{tabular}{|c|c|}
\hline Fertilization Media & $\begin{array}{c}\text { Fertilization Rate } \\
\text { Mean\% } \pm \text { SE }\end{array}$ \\
\hline TALP & $10.9 \pm 0.99^{\mathrm{c}}$ \\
$(7 / 64)$
\end{tabular}

The values with different superscripts in the same column differ significantly $(P<0.05)$

TALP: Tyrode - albumin - lactate - pyruvate media

In conclusion, the results of the present study show that the addition of gonadotrophins and estradiol-17 $\beta$ in TCM-199 supplemented with 20\% OBS has a favourable effect on 
in vitro maturation, while $\mathrm{Ca}^{2+}$ free Tyrode's medium is better for in vitro fertilization of buffalo follicular oocytes.

\section{Dozrávání a oplodňování folikulárních oocytů vodních buvolů in vitro $\mathrm{v}$ médiu obohaceném hormony a sérem říjících se buvolích krav}

V pokusu byl vyhodnocován vliv dvou zracích médií (TCM-199 a Ham F12) s a bez přídavku séra ř́íících se buvolích krav (EBS) a hormonů (FSH, LH, E2) na počty dozrávajících folikulů. Výsledky ukázaly významné zvýšení počtu dozrávajících folikulů $(P<0,05)$ při př́davku EBS a hormonů do TCM-199 ve srovnání s médiem Ham F12. Procenta zralých folikulů byla 77,$44 ; 55,17 ; 62,28$ a 26,62 pro TCM-199 + hormony + EBS, TCM-199 + hormony, TCM-199 + EBS a TCM-199. Zatímco pro Ham F12 + EBS + hormony, Ham F12 + hormony, Ham F12 + EBS a Ham F12 to bylo 32,85; 27,52; 31,38 a 13,46 procent. V modifikovaném Tyrodově pufru bez $\mathrm{Ca}^{2+}$ byl zaznamenán signifikantně vyšší $(P<0,05)$ počet oplodněných oocytů $(63,72 \%)$ ve srovnání s TALP $(10,9 \%)$ a IVF-TL (32,18 \%). Z pokusu vyplývá, že TCM-199 s prŕídavkem hormonů a EBS se jevil lepší pro in vitro dozrávání folikulù, zatímco pro in vitro fertilizaci buvolích folikulárních oocytů byl vhodnější modifikovaný Tyrodův pufr bez $\mathrm{Ca}^{2+}$.

\section{References}

ABDOON ASS, KANDIL OM, OTOI T, SUZUKI T 2001: Influence of oocyte quality, culture media and gonadotropins on cleavage rate and development of in vitro fertilized buffalo embryos. Anim Reprod Sci $\mathbf{6 5}$ : 215-223

CHAUHAN MS, KATIYAR PK, MADAN ML 1996: Influence of follicular stimulating hormone on in vitro maturation and cleavage of buffalo (Bubalus bubalis) oocytes after in vitro fertilization. Theriogenology 45: 243

CHAUHAN MS, KATIYAR PK, SINGLA SK, MANIK RS, MADAN ML 1997. Production of buffalo calves through in vitro fertilization. Indian J Anim Sci 67: 306-308

CHOHAN KR, HUNTER AG 2003. In vitro maturation and fertilization of water buffalo oocyte. Buffalo J 19: 91-101

CHOI YH, CARNEVALE EM, SIEDEL GE, SQUIRES EL 2001: Effect of gonadotropins on bovine oocyte matured in TCM-199. Theriogenology 56: 661-670

GLIEDT DW, ROSENKRANS CF, RORIE RW, MUNYON AL, PIERSON JN, MILLER GF, RAKES JM 1996: Effect of media, serum, oviductal cells and hormones during maturation on bovine embryo development in vitro. J Dairy Sci 79: 536-542

HANSEN PJ 2006: Realizing the promise of IVF in cattle - an overview. Theriogenology 65: 119-125

HYTTEL P 1997: Bovine cumulus oocyte disconnection in vitro. Anat Embryol 176: 41-44

IJAZ A, HUNTER AG 1989: Effect of washing and capacitating media pH on bull sperm motility, acrosome integrity and ability to penetrate zona-free hamster oocytes. J Dairy Sci 72: 2691-2699

KITO S, BAVISTER BD 1997: Gonadotropins, serum and amino acids after nuclear maturation, cumulus expansion, and oocyte morphology in hamster cumulus - oocyte complexes in vitro. Biol Reprod 56: 1281-1289

MAHMOUD GM, NAWITO MF 2003: Cytogenetic evaluation of in vitro matured buffalo oocytes in different culture condition. Egypt J Vet Sci 37: 105-116

NANDI S, RAGHU HM, RAVINDRANATHA BM, CHAUHAN MS 2002: Production of buffalo (Bubalus bubalis) embryos in vitro: Premises and promises. Reprod Domest Anim 37: 65-74

PAWSHE CH, PALANISAMY A, TANEJA M, JAIN SK, TOTEY SM 1996: Comparison of various maturation treatments on in vitro maturation of goat oocytes and their early embryonic development and cell numbers. Theriogenology 46: 971-981

RIZOS D, LONERGAN P, BOLAND MP, ARROYO-GARCIA R, PINTADO B, DELA-FUENTE J, GUTIERREZ-ADAN A 2002: Analysis of differential messenger RNA expression between bovine blastocyst produce in different culture system: implication for blastocyst quality. Biol Reprod 66: 589-595

RUSSELL DF, BAQIR S, BORDIGNON J, BETTS DH 2006: The impact of oocyte maturation media on early bovine embryonic development. Mol Reprod Develop 73: 1255-1270

SAMAD HA, KHAN IQ, REHMAN NU, AHMAD N 1998: The recovery, in vitro maturation and fertilization of Nili-Ravi buffalo follicular oocytes. Asian Austr J Anim Sci 11: 491-497

SMETANINA IG, TATARINOVA LV, KRIVOKHARCHENKO AS 2000: The effect of the composition of the culture media on bovine oocyte maturation and embryo development in vitro. Ontogenez 31: 139-143 
STAT CM, RUSSEL II FREED, Director Escop P Eisensmith, Deputy Director, Crop and Soil Science Department. Michigan State University, Version 1.3

TATEMOTO H, TERADA T 1998: Involvement of cumulus cells stimulated by FSH in chromatin condensation and activation maturation promoting factor in bovine oocytes. Theriogenology 49: 1007-1020 